\title{
Seasonal aggregation of juvenile whale sharks (Rhincodon typus) at Christmas Island, Indian Ocean
}

Received: 16 December 2008/Accepted: 7 March 2009/Published online: 27 March 2009

(C) Springer-Verlag 2009
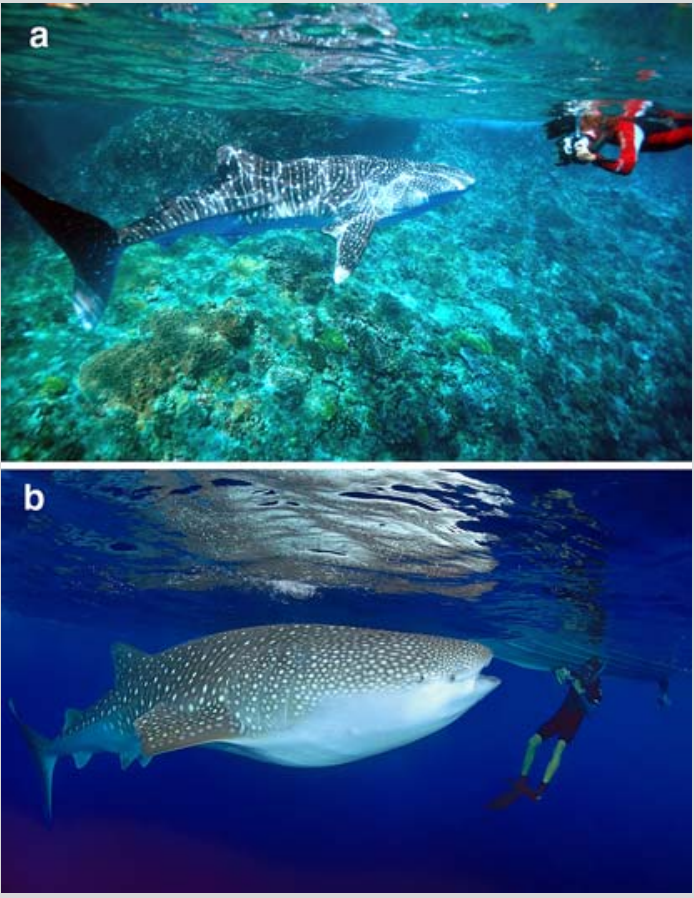

Fig. 1 a $1.8 \mathrm{~m}$ TL whale shark swimming over the shallow reef flat against the Christmas Island coastline (photo Gunter Noack). b An inquisitive juvenile whale shark, with damaged pectoral fins, approaches a person and boat (photo Justin Gilligan)
Whale sharks form seasonal feeding aggregations at particular coral reef locations (Colman 1997) that are critical to the life cycle of this vulnerable species. Our year-round observations at Christmas Island $\left(10^{\circ} 30^{\prime} \mathrm{S}, 105^{\circ} 40^{\prime} \mathrm{E}\right)$ from 1996-2008 revealed that whale sharks aggregate in summer ( $>90 \%$ observed between December and March). During the 2007-2008 summer aggregation (November 28-April 30), we used under- and above-water observations to estimate total length (TL; to nearest $0.25 \mathrm{~m}$ ) and the presence of people or boats alongside the shark was used as a reference. Photographs also confirmed length estimates. All observed individuals were probably juveniles (mean TL $=4.60 \mathrm{~m}$; range $=2.5-8 \mathrm{~m} ; n=82$ ), given maturation occurs over $9 \mathrm{~m}$ (Colman 1997). Swimming under the sharks and searching for claspers indicated a sex ratio of 1:3.3 male:female $(n=13)$, although male biased sex ratios have also been observed (M. Meekan, personal communication)

Records of small whale sharks (1-3 m TL) are lacking (Colman 1997), but several were observed at Christmas Island in the 2007-2008 summer (size range $2.5-3 \mathrm{~m}$ TL; $n=11$ ), with smaller individuals seen in previous summers (Fig. 1a). Christmas Island rises sharply out of deepwater $(>4,000 \mathrm{~m})$, and small whale sharks were seen in surface waters close to the coastline suggesting that the island may represent important juvenile habitat. At Christmas Island, whale sharks regularly approached divers and boats and this inquisitive behaviour may explain the scars seen on many individuals (Fig. 1b).

This seasonal aggregation of juvenile whale sharks coincides with the annual mass spawning of red land crabs (Gecarcoidea natalis). Whale sharks feed on the crab larvae (Meekan et al. in press), however, in summer 2007-2008, we also observed feeding (horizontal and vertical suction) as late as 74 days after the larvae had emerged from the sea. Numerous other species spawn during summer and these alternate food sources may become increasingly important due to the recent decline of the red crab population.

Acknowledgments Thanks to Wet ' $n$ ' Dry Adventures, Parks Australia, Christmas Island divers, Linda Cash, Gunter Noack.

\section{References}

Colman JG (1997) A review of the biology and ecology of the whale shark. J Fish Biol 51:1219-1234

Meekan MG, Jarman SN, McLean C, Schultz MB (in press) DNA evidence of whale sharks (Rhincodon typus) feeding on red crab (Gecarcoidea natalis) larvae at Christmas Island, Australia. Mar Freshw Res

J-P.A. Hobbs (凶) · A. J. Frisch

ARC Centre of Excellence for Coral Reef Studies, School of Marine and Tropical Biology, James Cook University, Townsville, QLD 4811, Australia

e-mail: jean-paul.hobbs@jcu.edu.au

T. Hamanaka

PO Box 121, Christmas Island 6798, Australia

C. A. McDonald · J. J. Gilligan · J. Neilson

16 Robinson Street, Anna Bay, NSW 2316, Australia

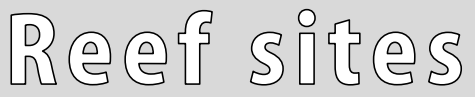

Coral Reefs (2009) 28:577 DOI 10.1007/s00338-009-0491-y 